\title{
Tradisi Sawer Penganten Sunda Di Desa Parigi Kecamatan Parigi Kabupaten Pangandaran
}

\author{
Yadi Kusmayadi \\ Program Studi Pendidikan Sejarah, FKIP, Universitas Galuh Ciamis
}

\begin{abstract}
Abstrak
Secara garis besar tradisi sawer panganten dilakukan setelah selesai akad nikah, pasangan pengantin duduk di kursi yang disimpan di depan rumah mempelai wanita yang disaksikan ratusan pasang mata. Tempat yang digunakan untuk upacara sawer merupakan tempat terbuka yang biasa disebut tempat panyaweran. Pasangan pengantin tersebut didampingi oleh seorang pemegang payung dan didepannya berdiri juru sawer atau biasa disebut penyawer. Juru sawer ini umumnya kaum wanita. Upacara sawer diawali dengan mengucapkan ijab kabul oleh penyawer, kemudian dilanjutkan dengan melantunkan syair/puisi sawer. Puisi sawer adalah puisi yang biasa dilagukan pada waktu upacara sawer seperti pada waktu upacara khitanan dan perkawinan. Kata sawer mengandung arti tabur atau sebar. Setelah melantunkan satu bait syair sawer, penyawer menyelinginya dengan menaburkan beras, irisan kunir, permen, uang logam dan bermacam - macam bunga rampai yang disimpan di dalam baskom (tempat menyimpan benda saweran) ke atas payung atau ke arah pengantin. Sehingga dalam waktu bersamaan, anak-anak ataupun orang dewasa yang bergerombol di belakang pengantin saling berebut memungut uang sawer dan permen.
\end{abstract}

Kata Kunci: Tradisi, Sawer Penganten, Sunda

\section{Pendahuluan}

Manusia merupakan makhluk yang berbudaya. Dengan akalnya manusia berpikir sehingga mampu menciptakan berbagai kebudayaan yang pada gilirannya tumbuh dan berkembang dalam suatu masyarakat. Kebudayaan dapat mengalami akulturasi bentuk, antara yang baru dengan yang sudah ada, sehingga bentuk dan coraknya bisa pula dipengaruhi oleh unsur kepercayaan yang bermacam-macam, seperti animisme, Dinamisme, Hindu-Budha serta Islam.

Kebudayaan diartikan sebagai upaya masyarakat untuk terus menerus secara dialektis menjawab setiap tantangan yang dihadapkan kepadanya dengan menciptakan berbagai prasarana dan sarana. Kebudayaan mempunyai fungsi yang sangat besar bagi manusia karena setiap manusia dalam masyarakat selalu menemukan kebiasaan baik atau buruk bagi dirinya. Kebiasaan yang baik akan diakui dan dilaksanakan oleh orang lain yang kemudian dijadikan dasar bagi hubungan antara orang-orang tertentu, sehingga tindakan itu menimbulkan norma atau kaidah. Norma atau kaidah itu disebut juga dengan adat istiadat (Musa Asy'ari, 1992: 95).

Mengenai adat istiadat dapat pula menyentuh penyelenggara upacara adat dan aktivitas ritual yang dianggap sangat mempunyai arti bagi warga pendukungnya, selain sebagai penghormatan terhadap leluhur dan rasa syukur terhadap Tuhan 
Yang Maha Kuasa, juga sebagai sarana sosialisasi dan pengukuhan nilai-nilai budaya yang sudah ada dan berlaku dalam kehidupan masyarakat sehari-hari (Tashadi, 1982: 2).

Demikian pula halnya yang terjadi di Desa Parigi Kecamatan Parigi Kabupaten Pangandaran, di sana muncul suatu bentuk upacara adat yang dianggap sakral dalam menggunakan simbol-simbol sehingga menarik untuk diteliti yaitu upacara perkawinan adat Sunda. Perkawinan menurut istilah ilmu Fiqih dipakai perkataan nikah dan jiwaz. Secara etimologi, nikah mempunyai arti sebenarnya dan arti kiasan. Arti sebenarnya dari nikah, ialah menghimpit, menindih atau berkumpul, sedang arti kiasannya ialah setubuh, atau mengadakan perjanjian pernikahan (Kamal Mukhtar, 1993: 1).

Sementara itu perkawinan adalah peristiwa yang sangat penting, karena menyangkut tata nilai kehidupan manusia, oleh sebab itu perkawinan merupakan tugas suci bagi manusia untuk mengembangkan keturunan yang baik dan berguna bagi masyarakat luas. Hal ini tersirat dalam tata cara upacara perkawinan. Semua kegiatan, termasuk segala perlengkapan upacara adat merupakan simbol yang mempunyai makna bagi pelaku upacara. Di samping itu pelaku memohon kepada Tuhan Yang Maha Esa agar semua permohonan dapat dikabulkan. (Thomas Wiyasa Bratawidjaja, 1990: 9). Simbol sebagai salah satu inti dari kebudayaan dan menjadi pertanda dari tindakan manusia selalu ada dan masuk dalam segala unsur kehidupan. Simbolsimbol yang berupa benda-benda, sebenarnya terlepas dari tindakan manusia. Sebaliknya, tindakan manusia harus selalu mempergunakan simbol-simbol sebagai media penghantar dalam komunikasi antar sesama. Penggunaan simbol dalam wujud budaya ternyata dilaksanakan dengan penuh kesadaran, pemahaman, dan penghayatan yang tinggi, yang dianut secara tradisional dari satu generasi ke generasi berikutnya (Budiono Herusatoto, 2000: 18).

Menurut kepercayaan masyarakat Desa Parigi Kecamatan Parigi, menjalankan adat istiadat warisan nenek moyang berarti menghormati para leluhur mereka. Segala sesuatu yang datangnya bukan dari ajaran leluhur masyarakat Desa Parigi Kecamatan Parigi, dan sesuatu yang tidak dilakukan leluhurnya dianggap sesuatu yang tabu. Ini menjadi aturan tak tertulis yang harus dijalani. Jika tidak dijalani mereka dianggap melanggar adat, dan diyakini akan menimbulkan malapetaka.

Upacara perkawinan dalam masyarakat Desa Parigi Kecamatan Parigi tidak semudahnya bisa digelar, banyak persiapan yang harus dijalani. Mulai dari merencanakan jadwal pelaksanaan berdasarkan perhitungan waktu yang tepat untuk menggelar hajat, sampai pada prosesi pelaksanaan ritualnya. Bulan Safar dan bulan Ramadhan merupakan bulan larangan 
(pamali) untuk menyelenggarakan acaraacara penting, seperti perkawinan, khitanan, membangun rumah dan upacara adat. Hal ini dikarenakan bulan tersebut bertepatan dengan upacara menyepi (Heni Fajria Rif'ati, 2002: 170).

Upacara perkawinan yang diselenggarakan di Desa Parigi Kecamatan Parigi sangat sederhana, pelakunya yaitu dari petugas KUA setempat, kuncen(Amil), kedua mempelai, orang tua mempelai, kerabat dekat mempelai. Tahapan-tahapan dalam upacara perkawinan yaitu, pra perkawinan yang dilakukan sebelum aqad nikah seperti melamar, Ngeuyeuk seureuh dan seserahan. Pelaksanaan perkawinan atau acara inti, seperti aqad nikah dan sungkem. Sesudah perkawinan, dilakukan setelah aqad nikah, seperti upacara sawer, nincak endog, buka pintu, ngariung dan munjungan. Pra perkawinan, yang pertama melamar, menyatakan permintaan untuk perjodohan dari seorang laki-laki pada seorang perempuan atau sebaliknya dengan perantara orang yang dipercayai.

Kedua, upacara ngeuyeuk seureuh, upacara ini biasanya dilakukan sehari sebelum perkawinan. Ketiga, upacara seserahan dalam upacara ini orang tua calon pengantin pria menyerahkan putranya kepada orang tua calon pengantin wanita sambil membawa barang-barang keperluan calon pengantin wanita. Perkawinan inti dari upacara yaitu aqad nikah, dilakukan dengan ijab kabul yang disaksikan oleh dua orang saksi. Terjadinya proses ijab-kabul ini biasa disebut dirapalan. Seluruh masyarakat Desa Parigi Kecamatan Parigi beragama Islam, maka perkawinannya dilaksanakan di depan penghulu dan kemudian dicatat oleh pegawai KUA setempat. Sesudah perkawinan ada beberapa ritual lain yang dilaksanakan yaitu, Pertama, upacara sawer dilakukan setelah akad nikah, pasangan pengantin dibawa ke tempat panyaweran atau tempat terbuka.

Selanjutnya panyawer melantunkan syair sawer, sambil menabur beras yang bercampur irisan kunir dan uang receh ke penonton. Kedua, upacara nincak endog. Endog (telur) di simpan diatas golodog dan mempelai laki-laki menginjaknya. Kemudian mempelai perempuan mencuci kaki mempelai laki-laki dengan air kendi. Setelah itu mempelai perempuan masuk ke dalam rumah, sedangkan laki-laki berdiri di muka pintu untuk melaksanakan upacara, Ketiga, yaitu buka pintu. Dalam upacara buka pintu terjadi tanya jawab antara kedua mempelai yang diwakili oleh masing-masing pendampingnya dengan cara dilagukan.

Keempat, upacara ngariung sambil menarik bakakak hayam, saling makan sesuap nasi kuning dan minum bersama atau disebut huap lingkung. Yang terakhir yaitu munjungan atau sungkem, kedua mempelai mengunjungi kedua orang tua mereka, kerabat dekat dan sesepuh. 


\section{Tinjauan Pustaka}

\section{A. Makna Perkawinan}

Nikah (kawin) menurut arti asli ialah hubungan seksual tetapi menurut arti majazi atau arti hukum ialah aqad atau perjanjian yang menjadikan halal hubungan seksual sebagai suami istri antara seorang pria dengan seorang wanita (Ramulya Idris, 1996 : 1). Pengertian perkawinan ini bisa ditinjau dari dua sudut pandang yaitu menurut Hukum Islam dan menurut Undang-Undang No. 1 tahun 1974 tentang Perkawinan dijelaskan sebagai berikut:

1. Menurut Hukum Islam

Terdapat perbedaan antara pendapat yang satu dengan yang lainnya mengenai pengertian perkawinan. Tetapi perbedaan pendapat ini sebetulnya bukan perbedaan yang prinsip. Perbedaan itu hanya terdapat pada keinginan para perumus untuk memasukkan unsur-unsur yang sebanyak-banyaknya dalam perumusan perkawinan antara pihak satu dengan pihak lain.

Walaupun ada perbedaan pendapat tentang perumusan pengertian perkawinan, tetapi dari semua rumusan yang dikemukakan ada satu unsur yang merupakan kesamaan dari seluruh pendapat, yaitu bahwa perkawinan itu merupakan suatu perjanjian perikatan antara seorang laki-laki dengan seorang wanita. Perjanjian bukan sekedar perjanjian seperti jual beli atau sewa menyewa tetapi perjanjian dalam perkawinan adalah merupakan suatu perjanjian yang suci untuk membentuk keluarga antara seorang lakilaki dengan seorang wanita.

Perkawinan adalah salah satu peristiwa yang sangat penting dalam kehidupan masyarakat kita. Sebab perkawinan tidak hanya menyangkut wanita dan pria calon mempelai saja, tetapi orang tua kedua belah pihak, saudarasaudaranya, bahkan keluarga-keluarga mereka masing-masing (Wignjodipuro, 1967: 122).

Perkawinan yaitu perkawinan yang dalam istilah agama disebut Nikah, adalah melakukan suatu aqad atau perjanjian untuk mengikatkan diri antara seorang lakilaki dengan wanita untuk menghalalkan hubungan kelamin antara kedua belah pihak, dengan dasar sukarela dan keridhoan kedua belah pihak untuk mewujudkan suatu kebahagiaan hidup berkeluarga yang diliputi rasa kasih sayang dan ketentraman dengan cara yang diridhoi oleh Allah (Soemiyati, 1999 : 8).

Perkawinan adalah suatu hal yang mempunyai akibat yang luas di dalam hubungan hukum antara suami dan istri. Dengan perkawinan itu timbul suatu ikatan yang berisi hak dan kewajiban, umpamanya, kewajiban untuk bertempat tinggal yang sama, setia kepada satu sama lain, kewajiban untuk memberi belanja rumah tangga, hak waris dan sebagainya. Suatu hal yang penting yaitu bahwa si istri seketika 
tidak dapat bertindak sendiri (Ali Afandi, $2000: 93)$.

Dari beberapa pengertian di atas dapat disimpulkan bahwa pengertian perkawinan menurut hukum Islam mengandung tiga aspek yaitu, aspek agama, aspek sosial dan aspek hukum.

a) Aspek Agama

Aspek agama dalam perkawinan ialah bahwa Islam memandang dan menjadikan perkawinan itu sebagai basis suatu masyarakat yang baik dan teratur, sebab perkawinan tidak hanya dipertalikan oleh ikatan lahir saja, tetapi diikat juga dengan ikatan batin dan jiwa. Menurut ajaran Islam perkawinan itu tidak hanya sebagai persetujuan biasa melainkan merupakan suatu persetujuan suci, dimana kedua belah pihak dihubungkan menjadi pasangan suami istri atau saling meminta menjadi pasangan hidupnya dengan mempergunakan nama Allah.

b) Aspek Sosial/Adat

Perkawinan dilihat dari aspek sosial memiliki artinya yang penting yaitu :

1) Dilihat dari penilaian umum pada umumnya berpendapat bahwa orang yang melakukan perkawinan mempunyai kedudukan yang lebih dihargai dari pada mereka yang belum kawin. Khusus bagi kaum wanita dengan perkawinan akan memberikan kedudukan sosial tinggi karena ia sebagai istri dan wanita mendapat hak-hak serta dapat melakukan tindakan hukum dalam berbagai lapangan mu'amalat, yang tadinya ketika masih gadis terbatas.

2) Sebelum adanya peraturan tentang perkawinan, dulu wanita bisa dimadu tanpa batas dan tanpa bisa berbuat apa-apa. Tetapi menurut ajaran agama Islam dalam perkawinan mengenai kawin poligami dibatasi empat orang, asal dengan syarat lakilaki bersifat adil dengan istrinya.

c) Aspek Hukum

Di dalam aspek hukum perkawinan diwujudkan dalam bentuk akad nikah yakni merupakan perjanjian yang harus dipenuhi oleh kedua belah pihak. Perjanjian dalam perkawinan mempunyai tiga karakter yaitu:

1) Perkawinan tidak dapat dilaksanakan tanpa unsur suka rela dari kedua belah pihak.

2) Kedua belah pihak (laki-laki dan perempuan) yang mengikat persetujuan perkawinan itu saling mempunyai hak untuk memutuskan perjanjian berdasarkan ketentuan yang sudah ada hukumnya.

3) Persetujuan perkawinan itu mengatur batas-batas mengenai hak dan kewajiban masing-masing pihak.

2. Undang-Undang No. 1 tahun 1974

Undang-undang No. 1 Tahun 1974 pasal 1, merumuskan bahwa perkawinan adalah ikatan lahir batin antara seorang pria 
dengan wanita sebagai suami istri dengan tujuan membentuk keluarga (rumah tangga) yang bahagia dan kekal berdasarkan Ketuhanan YME. Jika dibandingkan dengan rumusan tentang makna perkawinan menurut hukum Islam dengan UndangUndang No. 1 tahun 1974 pasal 1 tidak ada perbedaan prinsip antara keduanya.

\section{B. Tujuan Perkawinan}

Tujuan perkawinan adalah untuk memperoleh keturunan yang sah dalam masyarakat, dengan mendirikan sebuah kehidupan rumah tangga yang damai dan tentram. Tujuan perkawinan dilihat dari dua sudut pandang yaitu Hukum Islam dan Undang-Undang No. 1 tahun 1974 tentang Perkawinan, dijelaskan sebagai berikut:

1. Menurut Hukum Islam

Tujuan perkawinan dalam Islam adalah untuk memenuhi tuntutan hajat tabiat kemanusiaan, untuk berhubungan antara laki-laki dan perempuan dalam rangka mewujudkan suatu keluarga yang bahagia dorongan dasar cinta kasih, serta untuk memperoleh keturunan yang sah dalam masyarakat dengan mengikuti ketentuan yang telah diatur oleh syariah.

Selain itu, ada pendapat yang mengatakan bahwa tujuan perkawinan dalam Islam selain untuk memenuhi kebutuhan jasmani dan rohani manusia, sekaligus untuk membentuk keluarga, memelihara, dan meneruskan keturunan dalam menjalankan hidupnya di dunia, serta untuk mencegah perzinaan agar tercipta ketenangan dan ketentraman jiwa, keluarga dan masyarakat (Ramulya Idris, 1996 : 26).

Dari pernyataan tersebut dapat diperinci rumusan sebagai berikut:

a. Menghalalkan hubungan kelamin untuk memenuhi tuntutan hajat tabiat manusia

b. Mewujudkan suatu keluarga dengan dasar cinta kasih

c. Memperoleh keturunan yang sah.

Berdasarkan uraian tersebut, filosof Islam Ghazali (dalam Soemiyati, 1999: 12) mengemukakan tujuan dan faedah perkawinan menjadi lima macam yaitu:

a) Memperoleh keturunan yang sah yang akan melangsungkan keturunan serta memperkembangkan suku-suku bangsa manusia.

b) Memenuhi tuntutan naluriah hidup kemanusiaan

c) memelihara manusia dari kejahatan dan kerusakan

d) membentuk dan mengatur rumah tangga yang menjadi basis pertama dari masyarakat yang besar atas dasar kecintaan dan kasih sayang

e) Menumbuhkan kesungguhan berusaha untuk mencari rizki penghidupan yang halal dan memperbesar tanggung jawab.

Untuk lebih jelas mengenai tujuan dan faedah perkawinan, maka akan diuraikan sebagai berikut :

a) Untuk memperoleh keturunan yang sah yang akan melangsungkan keturunan serta akan memperkembangkan sukusuku bangsa manusia. Memperoleh 
keturunan dalam perkawinan bagi penghidupan manusia mengandung pengertian dua segi yaitu :

1) Untuk kepentingan diri pribadi.

Memperoleh keturunan merupakan dambaan setiap orang. Bisa dirasakan bagaimana perasan seorang suami istri yang hidup berumah tangga tanpa seorang anak, tentu kehidupannya akan sepi dan hampa. Disamping itu keinginan untuk memperoleh anak bisa dipahami, karena anak-anak itulah yang nantinya bisa diharapkan membantu ibu bapaknya di kemudian hari.

2) Untuk kepentingan yang bersifat umum atau universal.

Dari aspek yang bersifat umum atau universal karena anak yang menjadi penghubung atau penyambung keturunan seseorang dan yang akan berkembang untuk meramalkan dan memakmurkan dunia.

b) Memenuhi tuntutan naluriah hidup kemanusiaan.

Tuhan telah menciptakan manusia dengan jenis kelamin yang berlainan yaitu laki-laki dan perempuan. Sudah menjadi kodrat manusia bahwa antara laki-laki dan perempuan memiliki daya tarik. Daya tarik ini adalah kebirahian atau seksual. Sifat ini yang merupakan tabiat kemanusiaan. Dengan perkawinan pemenuhan tuntutan tabiat kemanusiaan dapat disalurkan secara sah. c) Memelihara manusia dari kejahatan dan kerusakan.

Dengan perkawinan manusia akan selamat dari perbuatan amoral, disamping akan merasa aman dari keretakan sosial. Bagi orang yang memiliki pengertian dan pemahaman akan nampak jelas bahwa jika ada kecenderungan lain jenis itu dipuaskan dengan perkawinan yang disyariatkan dengan hubungan yang halal.

Manusia (individu atau kelompok) akan menikmati adab yang utama dan akhlak yang baik. Dengan demikian masyarakat dapat melaksanakan risalah dan memikul tanggung jawab yang dituntut oleh Allah SWT.

d) Membentuk dan mengatur rumah tangga yang menjadi basis utama dari masyarakat yang besar atas dasar kecintaan dan kasih sayang.

Ikatan perkawinan adalah ikatan lahir batin yang berupa asas cinta dan kasih sayang merupakan salah satu alat untuk memperkokoh ikatan perkawinan. Di atas rasa cinta da kasih sayang kedua belah pihak yang melakukan ikatan perkawinan itu berusaha membentuk rumah tangga yang bahagia. Dari rumah tangga inilah kemudian lahir anak-anak, kemudian bertambah luas menjadi rumpun keluarga demikian seterusnya sehingga tersusun masyarakat besar.

Dengan demikian tanpa adanya perkawinan, tidak mungkin ada keluarga 
dan dengan sendirinya tidak ada pula unsur yang mempersatukan bangsa manusia da selanjutnya tidak ada peradaban. Oleh sebab itu dengan perkawinan akan terbentuk keluarga dan dengan keluarga itu akan tercipta peradaban (Soemiyati, 1999 : 17).

e) Menumbuhkan kesungguhan berusaha mencari rizki kehidupan yang halal dan memperbesar rasa tanggung jawab.

Pada umumnya sebelum melaksanakan perkawinan, tidak memikirkan soal penghidupan karena tanggung jawab mengenai kebutuhan kehidupan masih relatif kecil dan segala keperluan masih ditanggung orang tua. Tetapi setelah mereka berumah tangga mereka mulai menyadari akan tanggung jawab dalam mengemudikan rumah tangga. Suami sebagai kepala keluarga mulai memikirkan bagaimana mulai mencari rezeki yang halal untuk mencukupi kebutuhan rumah tangga.

Keadaan demikian akan menambah aktifitas kedua belah pihak, suami berusaha sungguh-sungguh dalam mencari rezeki lebih-lebih apabila mereka sudah memiliki anak.

Menurut Undang-Undang No. 1 tahun 1974 pasal 1 menjelaskan perkawinan ialah ikatan lahir dan batin antara pria dan wanita sebagai suami istri dengan tujuan membentuk keluarga (rumah tangga) yang bahagia dan kekal berdasar Ketuhanan Yang Maha Esa”. Dari penjelasan tersebut dapat diasumsikan bahwa tujuan pokok perkawinan adalah membentuk keluarga yang bahagia dan kekal. Untuk itu suami istri perlu saling membantu agar dapat mengembangkan kepribadiannya membantu dan mencapai kesejahteraan spiritual maupun material.

Selain itu, tujuan material yang akan diperjuangkan oleh suatu perjanjian perkawinan mempunyai hubungan yang erat sekali dengan agama, sehingga bukan saja mempunyai unsur lahir atau jasmani, tetapi unsur batin atau rohani juga mempunyai peranan penting (Penjelasan Undang-Undang No. 1 tahun 1974 tentang Perkawinan).

Maka perkawinan adalah suatu perjanjian yang diadakan oleh dua orang, dalam hal ini perjanjian antara seorang pria dan seorang wanita dengan tujuan material, yaitu membentuk keluarga (rumah tangga) yang bahagia dan kekal berdasarkan Ketuhanan Yang Maha Esa, sebagai asas pertama dalam Pancasila (Soedharyo Soimin, $1992: 6$ ).

Berdasarkan uraian tersebut maka tujuan perkawinan dapat dijelaskan sebagai berikut:

a. Melaksanakan ikatan perkawinan antara pria dan wanita yang sudah dewasa guna membentuk kehidupan rumah tangga.

b. Mengatur kehidupan seksual antara seorang laki-laki dan perempuan sesuai dengan ajaran dan firman Tuhan Yang Maha Esa. 
c. Memperoleh keturunan untuk melanjutkan kehidupan kemanusiaan dan selanjutnya memelihara pembinaan terhadap anak-anak untuk masa depan.

d. Memberikan ketetapan tentang hak kewajiban suami dan istri dalam membina kehidupan keluarga.

e. Mewujudkan kehidupan masyarakat yang teratur, tentram dan damai.

\section{Syarat-syarat Sahnya Perkawinan}

Suatu perkawinan dikatakan sah apabila sudah memenuhi syarat yang ditentukan. Syarat sahnya perkawinan dapat dilihat dari sudut pandang yaitu menurut Hukum Islam dan menurut Undang-Undang No. 1 tahun 1974 tentang Perkawinan, yang dijelaskan sebagai berikut:

1. Menurut Hukum Islam

Menurut hukum Islam untuk sahnya perkawinan diperlukan rukun dan syarat tertentu yang telah diatur dalam hukum Islam. Rukun perkawinan adalah hakikat dari perkawinan itu sendiri. Jadi tanpa adanya salah satu rukun, perkawinan tidak mungkin dilaksanakan. Sedangkan dimaksud syarat ialah suatu yang harus ada dalam perkawinan tetapi tidak termasuk hakikat perkawinan itu sendiri. Kalau salah satu syarat dari perkawinan itu tidak dipenuhi maka perkawinan itu tidak sah (Soemiyati, 1999: 30).

Adapun yang termasuk rukun perkawinan ialah sebagai berikut: a) Adanya pihak yang hendak melangsungkan perkawinan.

Pihak-pihak yang hendak melakukan perkawinan adalah mempelai laki-laki dan perempuan. Kedua mempelai harus memenuhi syarat supaya perkawinan menjadi sah hukumnya.

b) Wali

Perwalian disebut dengan penguasaan atau perlindungan. Arti perwalian ialah penguasaan penuh oleh agama untuk seseorang guna melindungi barang atau orang. Dengan demikian orang yang diberi kekuasaan disebut wali. Kedudukan wali dalam perkawinan adalah rukun dalam artian wali harus ada terutama bagi orang-orang yang belum mualaf, tanpa adanya wali suatu perkawinan dianggap tidak sah.

c) Dua orang saksi

Dua orang saksi dalam perkawinan merupakan rukun perkawinan oleh sebab itu tanpa dua orang saksi perkawinan dianggap tidak sah. Keharusan adanya saksi dalam perkawinan dimaksudkan sebagai kemaslahatan kedua belah pihak antara suami dan isteri. Misalkan, terjadi tuduhan atau kecurigaan orang lain terhadap keduanya maka dengan mudah keduanya dapat menuntut saksi tentang perkawinannya.

d) Adanya Sighat aqad nikah

Sighat aqad nikah adalah perkataan atau ucapan yang diucapkan oleh calon 
suami atau calon isteri. Sighat aqad nikah ini terdiri dari ijab dan qobul. Ijab yaitu pernyataan dari pihak calon isteri, yang biasanya dilakukan oleh wali pihak calon istri yang maksudnya bersedia dinikahkan dengan calon suaminya.

Qobul yaitu pernyatan atau jawaban pihak calon suami bahwa ia menerima kesediaan calon isterinya menjadi isterinya. Selain rukun beserta syarat yang sudah diuraikan di atas, masih ada hal yang harus dipenuhi sebagai syarat sahnya perkawinan, yaitu mahar.

Mahar adalah pemberian wajib yang diberikan dan dinyatakan oleh calon suami kepada calon isterinya dalam Sighat aqad nikah yang merupakan tanda persetujuan adanya kerelaan dari mereka untuk hidup bersama sebagai suami isteri (Soemiyati, 1999: 56).

Di dalam Undang-Undang No. 1 tahun 1974 terutama termuat asas dan prinsip perkawinan sebagai berikut:

a) Tujuan perkawinan adalah membentuk keluarga yang bahagia dan melengkapi agar dapat mengembangkan kepribadiann, membantu dan mencapai kesejahteraan spiritual dan material.

b) Dalam Undang-Undang ini dinyatakan bahwa suatu perkawinan adalah sah bilamana dilakukan menurut hukum masing-masing agama dan kepercayaan. Di samping itu setiap perkawinan harus dicatat menurut peraturan perundangundangan yang berlaku. Pencatatan setiap perkawinan adalah sama halnya dengan pencatatan peristiwa penting dalam kehidupan seseorang, misalnya kelahiran, kematian (surat keterangan), akta resmi (daftar pencatatan).

c) Undang-Undang menganut asas monogami. Hanya apabila dikehendaki oleh yang bersangkutan mengizinkan, suami dapat beristri lebih dari satu orang. Namun demikian, perkawinan suami dengan lebih dari seorang istri, meskipun hal itu dikehendaki oleh pihakpihak yang bersangkutan, hanya dapat dilakukan apabila memenuhi berbagai persyaratan tertentu dan diputuskan oleh pengadilan.

d) Undang-Undang menganut prinsip bahwa calon suami istri harus telah masak jiwa raganya untuk dapat melangsungkan perkawinan, agar supaya dapat mewujudkan tujuan perkawinan secara baik tanpa berakhir dengan perceraian dan mendapat keturunan yang baik dan sehat. Pria maupun wanita berumur 19 tahun (pria) dan wanita berumur 16 tahun.

e) Tujuan perkawinan adalah membentuk keluarga yang bahagia, kekal, dan sejahtera, maka Undang-Undang ini menganut prinsip mempersukar terjadinya perceraian. Untuk memungkinkan perceraian, harus ada alasan tertentu serta harus dilakukan di depan sidang Pengadilan. 
f) Hak dan kedudukan istri adalah seimbang dengan hak dan kedudukan suami. Dengan demikian sesuatu dalam keluarga dapat dirundingkan dan diputuskan bersama oleh suami dan istri.

Sejalan dengan asas dan prinsip perkawinan tersebut, Undang-Undang perkawinan meletakkan syarat ketat yang diatur dalam BAB II pasal 6-12 sebagai berikut:

1) Adanya persetujuan kedua belah pihak.

2) Adanya izin orang tua atau wali.

3) Batas umur untuk kawin.

4) Tidak terdapat larangan kawin.

5) Tidak terikat perkawinan yang lain.

6) Tidak bercerai untuk kedua kali dengan suami istri yang sama yang akan dikawini.

7) Bagi janda telah lewat masa tunggu.

8) Memenuhi tata cara perkawinan.

\section{Pernikahan Adat Sunda}

Hilman Hadi Kusuma (1990: 71) menjelaskan asas perkawinan menurut hukum adat sebagai berikut:

1. Perkawinan bertujuan membentuk keluarga rumah tangga dan hubungan kekerabatan yang rukun, damai, bahagia dan kekal.

2. Perkawinan tidak saja harus sah dilaksanakan menurut hukum agama dan atau kepercayaan, tetapi harus mendengar pengakuan anggota kerabat.

3. Perkawinan harus atas persetujuan orang tua dan anggota kerabat.
Masyarakat adat dapat menolak yang tidak diakui masyarakat adat.

Dari pengertian di atas dapat disimpulkan bahwa pernikahan adat Sunda merupakan peristiwa perkawinan antara pria dengan wanita yang bertujuan untuk menjamin ketenangan, kebahagiaan, kesuburan, serta menimbulkan hak dan kewajiban menurut aturan yang dimiliki masyarakat Sunda berlaku sejak dahulu.

Perkawinan yang dilakukan masyarakat Sunda dalam sifat wajar selalu memperhitungkan waktu. Pernikahan adat Sunda menggunakan perlengkapan tertentu dan melalui upacara upacara. Hal tersebut dapat dijelaskan sebagai berikut:

1. Sebelum Upacara Pernikahan

a) Neundeun Omong

Seorang pria atau orang tua bermaksud mempersunting gadis, maka gadis itu akan diselidiki dahulu keadaannya (apakah masih bebas/belum ada yang meminang atau mengikat). Hal ini dilakukan sendiri oleh orang tua atau utusannya, yang biasanya dengan cara berkunjung ke rumah gadis. Apabila belum terikat (bertunangan), maka pembicaraan yang semula berupa obrolan biasa dilanjutkan oleh pihak pria menanyakan tentang gadis tersebut.

Apabila dari pihak gadis menunjukkan kesan tanda-tanda menyetujui, pembicaraan ditingkatkan serius. Setelah ada persetujuan dari kedua belah pihak orang tua, baru pria 
dan gadis diberitahu. Hal ini dilakukan karena zaman dahulu pernikahan dilangsungkan atas kehendak orangtua di usia muda.

Sehingga tidak sedikit terjadi pernikahan dimana kedua mempelai sebelumnya tidak saling mengenal. Setelah bersepakat baru membicarakan dengan orang tua untuk selanjutnya menentukan waktu melamar/meminang.

b) Narosan (Ngalamar/Nyeureuhan)

Narosan adalah tindak lanjut dari neundeun omong, yaitu kunjungan kedua yang telah ditentukan dan disepakati kedua belah pihak. Orang tua (pria), keluarga dan sesepuh perwakilan melaksanakan acara narosan. Pihak pria membawa lamareun atau sirih pinang dan pakaian wanita sebagai pengikat. Maknanya adalah gadis yang dipinang sudah tidak bebas lagi atau sudah terikat.

c) Nyandakeun atau Seserahan

Seserahan/Nyandakeun adalah menyerahkan calon pengantin pria dengan membawa perlengkapan pernikahan sebagai kelanjutan ngalamar untuk diserahkan ke pihak gadis.

d) Ngebakan/Siraman

Ngebakan artinya memandikan dalam hal ini memandikan calon pengantin wanita yang maksud dan tujuannya adalah:

1) Mohon doa restu kepada ayah-ibu dan para sesepuh yang telah sukses dalam rumah tangganya dan diharapkan akan terlimpah pengaruh-pengaruh yang baik dari mereka.

2) Untuk mensucikan jiwa raga calon pengantin yang akan berumah tangga dengan harapan segala cita-citanya akan dapat terlaksana dengan lancar dan selamat.

e) Ngeuyeuk Seureuh

Pangeuyeuk (pelaksana) memberikan penjelasan tujuan dari ngeuyeuk seureuh, yaitu:

1) Memberikan kesempatan kepada calon pengantin untuk meminta izin kepada kedua orang tua disertai doa restu kedua orang tua, disaksikan keluarga.

2) Disaksikan kedua pihak keluarga bahwa pernikahan tidak ada unsur paksaan.

3) Memberikan nasihat kedua calon pengantin dengan lambang melalui benda pada alat ngeuyeuk seureuh.

2. Upacara Pernikahan

a. Penjemputan Calon Pengantin Pria

Penjemputan calon pengantin pria dilakukan oleh utusan dari pihak pengantin wanita. Setelah siap segala sesuatunya untuk pelaksanaan akad nikah dan sesuai pula dengan waktu yang telah disepakati, maka pihak calon pengantin wanita mengirimkan utusan untuk menjemput calon pengantin pria.

b. Ngabageakeun

Setibanya calon pengantin pria beserta rombongan di rumah calon 
pengantin wanita, diadakan penyambutan dengan pengalungan bunga kepada calon pengantin pria yang oleh ibu calon pengantin wanita. Kemudian calon pengantin pria dibawa ke tempat yang ditentukan untuk pelaksanaan akad nikah. Calon pengantin pria didudukkan di kursi sebelah kanan.

c. Akad Nikah

Setelah penghulu (KUA) dan saksi, calon pengantin wanita dibawa dari kamar pengantin oleh orang tuanya dan didudukkan di samping kiri calon pengantin. Sebelum ijab qobul (akad nikah) dimulai kedua calon pengantin dikerudung panjang berwarna putih. Ini melambangkan pernyataan dua insan yang masih murni baik lahir maupun bathin. Kerudung dibuka apabila kedua pengantin akan menandatangani naskah.

Setelah selesai upacara akad nikah, kedua pengantin dipersilahkan berdiri untuk serah terima mas kawin dan menerima buku nikah. Pengantin pria membacakan talak-talik dan selanjutnya melakukan pemasangan cincin kawin yang dipakaikan pada jari manis tangan kanan. Mula-mula pengantin pria yang melakukannya kepada pengantin wanita kemudian sebaliknya.

d. Sungkem

Sungkem adalah munjungan kedua pengantin ke petugas KUA, diteruskan dengan sembah sungkem ke orang tua pengantin wanita, dan sebaliknya. e. Wejangan

Wejangan biasanya pemberian nasihat ayah (orang tua) untuk membekali pengantin yang akan menempuh hidup berumah tangga.

f. Sawer

Upacara sawer adalah upacara memberi nasihat perkawinan dan dilakukan di panyaweran. Mengapa upacara nyaweran, karena pada zaman dahulu akad nikah dilaksanakan di masjid. Setelah selesai akad nikah mereka pulang ke rumah pengantin wanita dan sebelum masuk ke rumah mereka di sawer terlebih dahulu di panyaweran yang tempatnya antara halaman dan rumah atau tempat jatuhnya air dari atap/genting.

g. Meuleum harupat dan nincak endog

Upacara ini pengantin wanita dibawa ke tangga depan pintu, dan pengantin pria di depannya dan juru sawer berdiri di emper depan rumah.

h. Upacara Buka Pintu

Mula-mula pengantin pria mengetuk pintu 3 kali, kemudian pengantin wanita menanyakan siapa yang berani mengetuk pintu. Terjadilah tanya jawab yang dilakukan dengan pantun-pantun. Pada akhirnya pengantin wanita meminta agar pengantin pria membaca syahadat apabila benar-benar ia suaminya, setelah pembacaan syahadat maka pintu dibuka.

Pengantin pria melangkah masuk dan setelah disambut dengan munjungan 
pengantin wanita, kemudian berbimbing tangan (pacantel) kemudian menuju ke ruang dalam untuk melakukan upacara huap lingkung.

i. Upacara Huap Lingkung

Dilaksanakan dua tahap, yaitu: waktu dahulu dilakukan dengan duduk di bawah/di atas tikar, tetapi sekarang dengan duduk di kursi. Pengantin pria duduk berdampingan diapit oleh kedua orang tua dan keluarga.

j. Menerima Doa Restu

Dilanjutkan dengan acara memberi kesempatan ke pengantin untuk menerima doa restu dari keluarga dan handai taulan. Pengantin pria berdiri di sebelah kiri pengantin wanita dan sebaliknya orang tua pengantin wanita berdiri di sebelah kiri pengantin pria.

3. Upacara Setelah Pernikahan

$$
\text { Sebagai pelengkap upacara }
$$

tradisional yang sekarang sudah banyak dilupakan dan tidak dilaksanakan, adalah:

\section{a. Numbas}

Numbas upacara tradisional yang dilaksanakan beberapa hari setelah hari pernikahan, yaitu selamatan pasca pengantin sudah melaksanakan kewajibannya sebagai suami-istri atas dasar pengakuan. Orang tua pengantin pria setelah diberitahu putranya, bahwa telah selamat dan istrinya benar suci segera mengirimkan nasi tumpeng dan peralatan rumah tangga dan keperluan wanita yaitu pakaian sebagai tanda gembira. Setelah tumpeng dan kiriman lain diterima, maka orang tua pengantin wanita mengadakan selamatan dan membagikan tumpeng kepada tetangga.

b. Ngunduh Mantu

Syukuran di pihak pria bahwa pernikahan telah berlangsung dengan selamat. Selamatan dimaksudkan untuk menyatakan kegembiraan mendapat mantu yang telah direstui, sebagai rasa gembira karena tambahnya lingkungan keluarga, serta sebagai penghormatan terhadap keluarga pengantin wanita.

c. Ngarunghal (Melangkahi)

Zaman dahulu untuk meninabobokan hati yang akan dilangkahi harus dinikahkan terlebih dahulu meskipun pasangannya tidak seimbang. Hal ini sebagai syarat yang disebut kawin isuk pegat sore (kawin pagi-putus sore).

\section{Metode Penelitian}

Penelitian menggunakan pendekatan Sosiologi dan Antropologi. Pendekatan Sosiologi yaitu pendekatan yang dilakukan dengan meneropong segi sosial peristiwa yang dikaji, seperti golongan sosial mana yang berperan serta nilai-nilai yang dianutnya, dan hubungannya dengan golongan lain. Pendekatan Antropologi yaitu pendekatan yang dilakukan dengan memahami nilai-nilai tradisi yang masih dianut dalam masyarakat, perilaku, status, serta gaya hidup masyarakat. Keberhasilan 
suatu penelitian sangat ditentukan oleh kemampuan memilih serta menggunakan metode. Hasan (2003: 21) menjelaskan bahwa metode penelitian adalah tata cara bagaimana suatu penelitian dilaksanakan. Menurut Poerwadarminta (1991: 649) Metode adalah suatu cara yang lebih dipikirkan dan dapat memberikan arah serta petunjuk melakukan suatu penelitian.

Metode dalam penelitian ini adalah metode sejarah (historiografi). Ada lima langkah metode tersebut, yaitu: 1) pemilihan topik, 2) pengumpulan sumber, 3) verifikasi (kritik sejarah), 4) interpretasi, dan 5) penulisan (Kuntowijoyo, 2005: 91).

Dengan menempuh kelima langkah di atas, dapat dipastikan akan diperoleh hasil penelitian yang diharapkan.

\section{Hasil Dan Pembahasan}

Upacara tradisional sebagai wahana budaya leluhur masih memegang peranan penting dalam kehidupan masyarakat. Karena masyarakat meyakini dan mempercayai keberadaannya sehingga tak jarang menjadi keharusan yang wajib dipenuhi oleh masyarakat yang bersangkutan (Anita Setyowati dan Muhammad Hanif, 2014: 38). Upacara tradisional yang memiliki makna filosofis sampai sekarang masih dipatuhi oleh masyarakat. Hal ini disebabkan masyarakat merasa takut akan mengalami hal yang tidak diinginkan jika tidak melaksanakan upacara tradisional. Salah satu unsur budaya yang masih diakui keberadaannya dan dianggap sebagai warisan budaya yang penting adalah upacara perkawinan adat. Perkawinan dalam bahasa arab disebut nikah. Kedua konsep tersebut dalam kehidupan sehari-hari selalu disamakan pemahamannya.

Menurut Ahmad Azhar Basyir (1999: 4) perkawinan adalah suatu aqad atau perikatan untuk menghalalkan hubungan kelamin antara laki-laki dan perempuan dalam rangka mewujudkan kebahagiaan hidup keluarga yang diliputi rasa ketentraman serta kasih sayang dengan cara yang diajarkan oleh agama Islam. Salah satu upacara perkawinan adat Sunda adalah upacara perkawinan masyarakat Desa Parigi. Upacara perkawinan adat Parigi di dominasi nilai-nilai dan ajaran agama yang dianut yakni Islam.

Meskipun dalam prosesi perkawinan yang diwariskan leluhur, namun secara esensial diwarnai ajaran-ajaran Islam. Perkawinan yang dilakukan merupakan perpaduan antara nilai istiadat, ajaran agama dan undang-undang yang telah ditetapkan pemerintah Indonesia. Dalam upacara perkawinan di Desa Parigi Kecamatan Parigi Kabupaten Pangandaran terkandung nilai dan norma yang berfungsi mengatur dan mengarahkan tingkah laku masyarakat. Dengan demikian, tata upacara perkawinan adat Sunda di Parigi merupakan perpaduan unsur sifat, karakteristik, kepercayaan dan agama yang saling 
menopang satu sama lain. Menurut Thomas Wiyasa (1990: 11) bahwa dalam tata upacara perkawinan adat Sunda, sebelum diadakan upacara perkawinan adat, biasanya didahului dengan beberapa tahap upacara. Tahap upacara dilaksanakan sesuai ekonomi dan situasi yang ada, namun tidak boleh menyimpang dari tata cara pokok adat istiadat Sunda.

Tahap upacara perkawinan di Desa Parigi diuraikan sebagai berikut:

1. Melamar atau Meminang

Melamar adalah satu tahapan yang menunjukkan (menyatakan) permintaan untuk perjodohan dari seorang laki - laki pada perempuan dengan perantara seseorang yang dipercayai. Tujuan lamaran ini adalah untuk menanyakan kepada kedua orang tua perempuan, apakah anak yang dimaksud masih sendiri atau sudah ada yang punya. Dalam Islam pinangan disunnahkan dan dianjurkan kepada manusia.

Di kalangan masyarakat bila akan menikahkan anaknya, orang tua pria perlu berkunjung ke rumah orang tua wanita yang menjadi pilihan anaknya. Hal ini perlu dilakukan dalam rangka mendapatkan keterangan lebih jelas mengenai data pribadi wanita yang dimaksud, seperti apakah wanita itu, sudah mempunyai pacar atau belum dan juga hal lain yang dipandang perlu dalam memperdalam pengetahuan terhadap calon pasangan yang akan menjadi teman hidup anaknya, tahapan ini disebut juga dengan nanyaan. Apabila wanita yang dimaksud belum mempunyai pacar dan orang tuanya juga setuju dengan pria yang diajukan, maka terjadilah perembukan yang dinamakan Neundeun omong.

Sejak peristiwa ini, maka kedua belah pihak mulai dengan saling mengunjungi dan bila ada rejeki mereka saling berkirim makanan, sehingga hal itu akan menimbulkan hubungan yang erat dari kedua belah pihak.

\section{Ngeuyeuk Seureuh}

Biasanya diselenggarakan malam hari sebelum akad nikah di rumah orang tua calon pengantin wanita. Pelaksanaannya dipimpin oleh seseorang yang tahu tentang upacara ini yang disebut pengeuyeuk. Upacara ngeuyeuk seureuh ini dilakukan pada malam hari. Prosesi dalam upacara ini adalah kedua mempelai mempersiapkan peralatan pengantin, seperti pakaian pengantin laki-laki dan wanita, sepatu, kosmetik, tikar, peralatan sawer. Semua barang tersebut ditumpuk dalam ayakan (alat penyaring).

Tumpukan paling bawah sendiri biasanya ditaruh seureuh bertangkai. Setelah semua peralatan lengkap, ayakan yang berisi perlengkapan pengantin diikat/ditutupi dengan kain, lalu diangkat oleh pasangan pengantin, untuk ditaruh diatas kepulan asap 
kemenyan sambil dibacakan sambil dibacakan do'a oleh kuncen. Saat memegang perlengkapan upacara ngeuyeuk seureuh ini tidak boleh lepas, keduanya harus saling bekerja sama. Tujuan acara ini adalah dalam hidup rumah tangga harus tolong menolong. Pembacaan do'a selesai, maka selesai pula upacara ngeuyeuk seureuh.

3. Upacara Seserahan

Menyerahkan putranya ke orang tua pengantin putri sambil membawa barang keperluan calonnya. Calon pengantin pria cukup menyerahkan uang saja. Jumlah dan nilai barang tergantung kemampuan laki-laki yang disepakati pihak perempuan. Biasanya barang seserahan adalah uang, pakaian perempuan, perhiasan seperti gelang, kalung dan alat kecantikan wanita.

\section{Upacara Pada Saat Perkawinan}

Upacara perkawinan lazimnya dilangsungkan di rumah orang tua calon pengantin wanita. Pada hari perkawinan pria diantar iring-iringan dari suatu tempat yang telah ditentukan menuju ke rumah calon pengantin wanita. Biasanya pengantin pria dipayungi. Bila pengantin pria berdekatan rumah dengan pengantin wanita, maka calon pengantin pria langsung menuju calon pengantin wanita. Adapun tahap pelaksanaan perkawinan berikut:

\section{Akad Nikah}

Sebelum mempelai melangsungkan akad nikah, lebih dulu harus memenuhi persyaratan administrasi. Sebagaimana tercermin dalam salah satu falsafah hidup mereka, yaitu Parentah gancang lakonan, panyaur geura temonan, panundut gancang caosan. Artinya perintah dan permintaan dari aparat pemerintah harus segera dilaksanakan.

Upacara akad nikah dilakukan dengan ijab kabul yang disaksikan oleh dua orang saksi yang disebut dirapalan. Setelah ijab diucapkan, segera disusul dengan ucapan kabul oleh mempelai lakilaki sebagai tanda penerimaan. Sehingga dengan selesainya ijab kabul tersebut, kedua mempelai sudah sah menjadi suami istri. Masyarakat Desa Parigi mayoritas beragama Islam, maka dalam upacara perkawinan adat di kampung ini selain ada ritual yang berasal dari adat setempat juga disesuaikan dengan ketentuan syari'at agama Islam.

2. Sungkem

Upacara ini merupakan upacara adat yang sangat berkesan. Upacara ini menimbulkan perasaan terharu yang luar biasa, baik bagi mempelai dan hadirin. Awalnya pengantin wanita sungkem kepada ibunya, kemudian bertukar, pengantin laki - laki kepada mertua perempuan dan pengantin wanita sungkem kepada ayahnya, begitu seterusnya. Arti sungkem yang dilakukan oleh pengantin ke orang tua dan pinisepuh menunjukkan tanda bakti dan rasa terima kasih atas bimbingan dari 
lahir sampai perkawinan. Selain itu kedua pengantin mohon do'a restu dalam membangun kehidupan rumah tangga yang baru agar selalu mendapatkan berkah dan rahmat Tuhan.

\section{Upacara Setelah Perkawinan}

Walaupun pasangan pengantin sudah dinyatakan sah sebagai suami istri, namun karena mereka merupakan bagian dari masyarakat adat, maka upacara perkawinan masih harus dilanjutkan dengan prosesi adat dan tradisi leluhurnya.

\section{Upacara Sawer}

Upacara sawer dilakukan setelah selesai akad nikah, pasangan pengantin duduk di kursi yang ditaruh di depan rumah mempelai wanita yang disaksikan ratusan pasang mata. Tempat yang digunakan untuk upacara sawer merupakan tempat terbuka yang biasa disebut tempat penyaweran. Pasangan pengantin tersebut didampingi oleh seorang pemegang payung dan didepannya berdiri juru sawer atau biasa disebut penyawer. Juru sawer ini umumnya kaum wanita.

Upacara sawer diawali dengan mengucapkan ijab kabul oleh penyawer, kemudian dilanjutkan dengan melantunkan syair/puisi sawer. Puisi sawer adalah puisi yang biasa dilagukan pada waktu upacara sawer seperti pada waktu upacara khitanan dan perkawinan. Kata sawer mengandung arti tabur atau sebar. Setelah melantunkan satu bait syair sawer, penyawer menyelinginya dengan menaburkan beras, irisan kunir, permen, uang logam dan bermacam-macam bunga rampai yang disimpan di dalam baskom ke atas payung atau ke arah pengantin. Sehingga dalam waktu bersamaan, anak-anak yang bergerombol di belakang pengantin saling berebut memungut uang sawer dan permen sebanyak-banyaknya.

Begitu seterusnya sampai isi baskom habis terkuras. Adapun sajak atau syair yang dipakai oleh masyarakat Desa Parigi dalam upacara sawer adalah memakai sekar macapat yaitu dandanggula, kinanti, sinom, dan asmarandana (Prawirasugandi, 1964: 80). Syair sawer merupakan tembang atau lagu yang dinyanyikan oleh juru sawer setelah ijab qabul dalam prosesi perkawinan adat Sunda. Syair sawer biasnya terdiri dari pendahuluan atau pembukaan, isi (nasihat kepada pengantin wanita dan pengantin lelaki), dan penutup. .

2. Upacara Nincak Endog (injak telur)

Usai upacara sawer dilanjutkan dengan upacara nincak endog. Kedua pengantin dipersilahkan berdiri menuju tangga rumah. Pengantin pria berdiri di bawah tangga dan pengantin wanita berdiri di anak tangga rumah yang lebih tinggi sambil membawa kendi dan saling berhadapan muka. Dalam pelaksanaannya pengantin pria langsung menginjak endog (telur) yang ditaruh di atas papan ijakan. Telur itu harus pecah dengan sekali menginjaknya. Kemudian mempelai perempuan mencuci kaki mempelai laki-laki 
dengan air kendi sambil diterangi oleh lilin/Pelita, dan kendi yang kosong langsung dihempaskan ke tanah hingga hancur. Setelah itu mempelai perempuan masuk ke dalam rumah, sedangkan mempelai laki laki berdiri di muka pintu untuk melaksanakan upacara buka pintu.

3. Upacara Muka Panto (Buka Pintu)

Upacara muka panto merupakan suatu percakapan atau proses tanya jawab antara pengantin pria yang berada di luar rumah dengan pengantin wanita yang berada di dalam rumah. Proses tanya jawab itu dilaksanakan oleh kedua mempelai sendiri, tetapi pada umumnya diwakili oleh masing-masing pendampingnya atau ahlinya yaitu juru mamaos dengan cara dilagukan. Hal ini karena syair merupakan tanya jawab dan mengandung Petuahpetuah atau nasihat-nasihat.

Upacara muka panto dimulai dengan ketukan pintu tiga kali oleh pengantin pria atau pendampingnya, sebagai pembuka dalam percakapan ini biasanya mempelai laki-laki mengucapkan salam 'Assalamu'alaikum' yang kemudian dijawab oleh mempelai perempuan 'Wa'alaikum salam'. Selanjutnya terjadi tanya jawab kedua mempelai atau melalui pendampingnya yang berakhir dengan permintaan dari mempelai wanita agar mempelai pria mengucapkan do'a atau Pembacaan Syahadat. Dalam syair, terkandung janji setia. Setelah upacara buka pintu selesai mempelai pria diperbolehkan masuk ke dalam rumah.

4. Upacara Munjungan (Berkunjung)

Usai acara muka panto dilanjutkan dengan cara munjungan. Kedua mempelai bersujud sungkem kepada kedua orang tua mereka, sesepuh, kerabat dekat, dan kuncen. Akhirnya selesai rangkaian upacara perkawinan. Sebagai ungkapan rasa terima kasih kepada para undangan, tuan rumah membagikan makanan. Masing-masing mendapatkan boboko (bakul) yang berisi nasi dengan lauk pakunya dan rigen yang berisi opak, wajit, rangginang, dan pisang.

$$
\text { Upacara Munjungan biasanya }
$$
dilaksanakan selama seminggu. Beberapa hari setelah perkawinan, kedua mempelai wajib berkunjung kepada saudarasaudaranya, baik pihak laki-laki maupun pihak perempuan. Maksudnya untuk menyampaikan ucapan terima kasih atas bantuan mereka selama acara perkawinan yang telah lalu. Biasanya sambil berkunjung kedua mempelai membawa nasi dengan lauk pakunya.

Usai beramah-tamah, ketika kedua mempelai berpamitan akan pulang, maka pihak keluarga yang dikunjungi memberikan hadiah seperti peralatan untuk keperluan rumah tangga mereka.

\section{Makna Simbol Tradisi Sawer Panganten Desa Parigi}

Setiap bangsa atau suku bangsa memiliki kebudayaan sendiri yang berbeda dengan kebudayaan bangsa lain. Dalam 
mengimplementasikan simbol, tidak terlepas dari sikap emosional seseorang dalam memahami simbol tersebut. Inti dari emosional keagamaan dipandang tidak dapat diekspresikan, karena hal itu merupakan pikiran yang bersifat simbolik.

Meskipun demikian, simbolisme mempunyai potensi yang istimewa. Menurut Elizabeth (1994: 16) bahwa simbol secara emosional mampu membangkitkan perasaan dan ketentraman dari sekedar formulasi verbal dari benda-benda yang mereka percayai sebagai simbol. Sampai sekarang, simbol merupakan pendorong yang kuat bagi timbulnya perasaan manusia untuk melakukan sesuatu.

Sejak zaman nenek moyang, prosesi perkawinan diperlakukan sebagai suatu yang penuh dengan ritual dan syarat dengan simbol kehidupan dilihat dari kelengkapannya. Prosesi yang dilaksanakan dalam upacara perkawinan tidak hanya memuat rangkaian simbol tanpa makna. Tetapi merupakan rangkaian yang mempunyai arti mendalam dan sering kali berkaitan dengan unsur religi.

Simbol dalam upacara bertujuan sebagai sarana untuk menunjukkan secara semu tujuan yang dilakukan masyarakat. Dalam simbol juga terdapat misi luhur yang dapat dipergunakan untuk mempertahankan nilai budaya dengan melestarikannya. Adapun makna simbol dalam prosesi perkawinan adat Sunda di
Desa Parigi Kabupaten Pangandaran sebagai berikut:

\section{Upacara Ngeuyeuk Seureuh}

Upacara ngeuyeuk seureuh ini lambang nasehat bagi anak laki-laki dan perempuan yang akan menjadi suami istri. Kata ngeuyeuk itu berpegang bersendi. Maksudnya memberi tanda bahwa ketika kedua orang telah berumah tangga, maka harus berpegangan antara laki-laki dan perempuan, menunjukkan bahwa laki-laki bergantung pada perempuan dan, sebaliknya. Jangan ada pertikaian, harus seiya sekata dengan damai, hingga mencapai usia yang tinggi (Prawirasuganda, 1964: 76).

Adapun perlengkapan dalam upacara ini mengandung makna:

a. Ayakan: memberi petunjuk kedua mempelai agar dalam melakukan sesuatu harus diayak dahulu, diperhitungkan, dan dipertimbangkan supaya tidak menghasilkan penyesalan.

b. Seureuh bertangkai, yang terdiri dari beberapa tangkai seureuh, melambangkan dua insan berlainan jenis yang bukan saudara sekandung.

c. Ramuan sirih seperti gambir, kapur sirih melambangkan kepaduan dua insan.

d. Pakaian pengantin yang ditaruh diatas kepulan asap kemenyan melambangkan suami akan bertanggung jawab terhadap kebutuhan sandang istri, dan pada waktu upacara bisa berjalan dengan baik. 
2. Upacara Seserahan

$$
\text { Adapun waktu pelaksanaannya }
$$
bervariasi. Ada yang melaksanakan satu minggu sebelum pelaksanaan aqad nikah, ada yang satu hari sebelumnya dan bahkan ada yang melaksanakannya pada hari pelaksanaannya aqad nikah. Tujuan upacara ini adalah menyerahkan barang atau uang untuk membantu pelaksanaan upacara perkawinan. Perlengkapan yang digunakan dalam upacara ini adalah sebagai berikut:

a. Uang sebagai lambang pengikat atau panyangcang. Artinya tidak boleh lepas dan tidak boleh ada yang mengganggu.

b. Seperangkat perhiasan untuk lambang pengikat batin calon suami istri agar tidak berpaling pada orang lain. Selain itu merupakan hadiah pertunangan dan pernyataan kesungguhan.

c. Peralatan dapur. Artinya jika nanti sudah berumah tangga, tidak sulit untuk mencari lagi.

3. Upacara Sawer

Syair sawer dalam upacara perkawinan adat Sunda bertujuan untuk menyampaikan pengajaran dan memberi nasihat tentang kehidupan berumah tangga dan bermasyarakat, sekaligus menggembirakan mempelai yang berbahagia. Selain syairnya penuh dengan nasihat hidup, barang yang disawerkan pun mempunyai makna.

Adapun makna simbol dari alat-alat atau bahan-bahan dalam upacara sawer adalah sebagai berikut: a. Beras putih: simbol bekal pokok kehidupan bahagia.

b. Kunyit: simbol agar mereka bersikap jujur kepada masing-masing pihak.

c. Beragam bunga rampai: simbol keharuman nama baik rumah tangga.

d. Uang logam: simbol kekayaan atau kecukupan.

e. Payung: simbol pelindung dalam menjalani hidup, harus bersikap hati-hati karena godaan bisa datang dari mana dan kapan saja. Suami wajib menjadi pelindung untuk istri dan anaknya kelak.

f. Permen: simbol ramah tamah dan manis budi.

Syair-syair yang dinyanyikan dalam upacara adat nyawer sebagai berikut:

KIDUNG SAWER

Pangapunten kasadaya

Kanu sami araya

Rehna bade nyawer heula

Ngedalkeun eusi werdaya

Dangukeun ieu piwulang

Tawis nu mikamelang

Teu pisan dek kumalancang

Megatan ngahalang-halang

Bisina tacan kaharti

Tengetkeun masing rastiti

Ucap lampah ati-ati

Kudu silih beuli ati

Lampah ulah pasali

Singalap hayang waluya

Upama pakiya-kiya

Ahirna matak pasea

\section{Meuleum Harupat (Membakar Harupat)}

Mempelai pria memegang batang harupat, pengantin wanita membakar dengan lilin sampai menyala. Harupat yang sudah menyala dimasukkan dalam kendi 
yang dipegang mempelai wanita, diangkat dan dipatahkan lalu dibuang. Hal ini melambangkan nasihat kedua mempelai untuk bersama dalam memecahkan persoalan rumah tangga. Fungsi istri dengan memegang kendi berisi air adalah untuk mendinginkan persoalan yang membuat pikiran dan hati suami tidak nyaman.

\section{Buka pintu}

Diawali mengetuk pintu tiga kali. Diadakan tanya jawab dengan pantun bersahutan dari dalam dan luar pintu rumah. Setelah kalimat syahadat dibacakan, pintu dibuka. Pengantin masuk menuju pelaminan. Dialog pengantin perempuan dengan pengantin laki-laki berikut ini:

\section{KENTAR BAYUBUD}

Istri

: Saha eta anu kumawani Taya tata taya bemakrama Ketrak- ketrok kana panto

Laki-laki : Geuning bet jadi kitu Api-api kawas nu pangling Apan ieu teh engkang Hayang geura tepung Tambah teu kuat ku era Da diluar seueur tamu nu ningali

Istri : Euleuh karah panutan

Makna penaburan dalam upacara sawer tersebut bukan membuang bahanbahan secara percuma, tetapi sebagai petunjuk kedua mempelai bila kemudian hari hidup senang, mulia dan bahagia, harus senang menolong dan membantu sesama dengan sedekah.

4. Upacara Nincak Endog (Injak Telur)

Upacara ini melambangkan istri harus rela melayani suami, sedangkan suami memenuhi kewajiban memberi nafkah lahir dan batin. Bahan-bahan dalam upacara nincak endog sebagai simbol dan nasihat untuk keselamatan kedua mempelai. Bahan- bahan tersebut terdiri dari:

a. Telur ayam dipecahkan

Melambangkan kerelaan pengantin wanita dipecahkan kegadisannya, sebab sudah menjadi kodrat istri melayani suami. Di samping itu memberikan isyarat bahwa buah pergaulan suami istri akan menghasilkan keturunan berupa lendir yang menyerupai telur. Manusia lahir dari bahan yang sama, maka tidak ada alasan untuk merasa angkuh, sombong dan merasa lebih dari yang lain.

b. Air bening dalam kendi kecil.

Bermakna alat pembersih dan sebagai pendinginan atau penentraman suasana. Ada satu isyarat bahwa istri sangat senang melayani suami. Asal suami ketika masuk dalam rumah membawa hati yang bersih, jernih dan segar.

c. Lilin / Pelita.

Simbol sebagai penerang kedua mempelai dalam menjalankan rumah tangga, agar saling asah, asuh, dan asih.

d. Kendi yang dipecahkan adalah menyatakan kepuasan hati.

e. Papan atau injakan yaitu simbol istri harus menuruti bimbingan suami.

5. Upacara Buka Pintu

Maknanya adalah menyatakan istri yang selalu berada di rumah harus sabar menunggu suami pulang, dan suami ketika 
hendak masuk rumah harus memberi salam atau mengetuk pintu dahulu. Upacara ini mempunyai makna sebagai pembelajaran kepada pengantin dalam tata krama di rumah antara suami dan istri, dan diajarkan bagaimana seharusnya istri menerima suami yang baru datang serta bagaimana seharusnya suami jika masuk rumah.

\section{Penutup}

\section{A. Simpulan}

Upacara tradisional sebagai wahana budaya leluhur masih memegang peranan penting dan memiliki makna filosofis. Salah satu warisan budaya yang berperan dalam perjalanan hidup orang adalah upacara perkawinan adat. Upacara sawer salah stu bentuk upacara tersebut yang dilakukan setelah selesai akad nikah dengan tempat untuk upacara sawer disebut penyaweran. Upacara sawer diawali mengucapkan ijab kabul oleh penyawer, dilanjutkan dengan melantunkan syair sawer.

Syair sawer adalah puisi yang dilagukan waktu upacara sawer. Kata sawer berarti tabur atau sebar. Setelah melantunkan satu bait syair sawer, penyawer menyelinginya dengan menaburkan beras, irisan kunir, permen, uang logam dan bunga rampai di dalam baskom ke atas payung atau arah pengantin. Sehingga dalam waktu bersamaan, anakanak yang bergerombol di belakang pengantin saling berebut uang sawer dan permen sampai isi baskom habis.

\section{B. Saran}

$\begin{array}{lll}\text { Diharapkan } & \text { kepada generasi } \\ \text { penerus dapat memelihara dan }\end{array}$ melestarikan upacara tersebut. Hendaknya mengerti makna dan arti dari prosesi upacara baik simbol dan perlengkapan yang digunakan, sehingga tidak hanya melaksanakan tanpa mengerti makna dan tujuan dari pelaksanaan upacara tradisi sawer panganten.

\section{Daftar Pustaka}

1971. Manusia dan Kebudayaan di Indonesia, Jakarta: Djambatan.. 1989. Pengantar Ilmu Antropologi, Jakarta: Aksara Baru. Ahmad Azhar Basyir. 1999. Hukum Perkawinan Islam. Yogyakarta: UII Press.

Anita Setyowati dan Muhammad Hanif. 2014. Peran Perempuan Dalam Tradisi Upacara Bersih Desa (Studi Kasus Di Desa Kiringan Kecamatan Takeran Kabupaten Magetan). Agastya: Jurnal Sejarah Dan Pembelajarannya. Volume 4 Nomor 01 Tahun 2014: 37-57.

Dudung Abdurahman. 2003. Pengantar Metode Penelitian. Yogyakarta: Kurnia Kalam Semesta.

Hans J Daeng. 2002. Manusia, Kebudayaan dan Lingkungan: Tinjauan Antroplogis. Yogyakarta: Pustaka Pelajar.

Heni Fajria Rifati dkk. 2002. Kampung Adat dan Rumah Adat di Jawa Barat. Dinas Kebudayaan dan Pariwisata Propinsi Jawa Barat.

Hilman Hadi Kusuma. 1990. Hukum Perkawinan Adat. Bandung: Citra Aditya Bakti.

Kamal Mukhtar. 1993. Asas - Asas Hukum Islam tentang Perkawinan. Jakarta: Bulan Bintang.

Koentjaraningrat. 1965. Beberapa Pokok Antropologi Sosial. Jakarta: Dian Rakyat. 
Kuntowijoyo. 2005. Metodologi Penelitian Sejarah: Jakarta PT Gramedia Pustaka Utama

Kuntowijoyo. 2006. Budaya dan Masyarakat. Edisi Paripurna. Yogyakarta: Tiara Wacana.

Maman Sumantri (et al.). 1994. Kamus Bahasa Sunda-Bahasa Indonesia. Jakarta: Pusbinbang Bahasa Depdikbud.

Musa Asy'ari. 1992. Manusia Pembentuk Kebudayaan Dalam Al-Qur'an. Yogyakarta: LESFI.

Prawirasuganda. 1964. Upacara Adat di Pasundan. Bandung: Sumur Bandung.

Sulaiman Rasjid. 1954. Fiqih Islam. Jakarta : Attahiriyah.

Sutrisno Hadi. 1992. Metodologi Research, jilid II. Yogyakarta: Andi Offset.

Suwardi Endraswara. 2006. Metodologi Penelitian Kebudayaan. Yogyakarta : Gadjah Mada University Press.

T.0. Ihromi. 1996. Pokok-pokok Antropologi Budaya. Jakarta: Yayasan Obor Indonesia.

Thomas Wiyasa Bratawidjaja. 1990. Upacara Perkawinan Adat Sunda. Jakarta: Pustaka Sinar Harapan.

Vredenbregt, Jacob. 1983. Metode dan Teknik Penelitian Masyarakat. Jakarta: PT Gramedia.

Winarno Surakhmad. 1982. Pengantar Penelitian Ilmiah: Metode, Dasar, dan Teknik. Bandung: Tarsito.

Zakiyah Daradjat. 1995. Ilmu Fiqh jilid II. Jakarta: Dana Bhakti Wakaf. 